\title{
The relationship of stock returns, interest rates, economic activity and inflation: Evidence from Latin America
}

\author{
Eurilton Araújo ${ }^{\dagger}$ \\ $I B M E C-S P$ \\ Felipe Augusto da Silva Bastos * \\ $I B M E C-S P$
}

\begin{abstract}
This study employs a four-variable vector autoregressive (VAR) model to investigate the relationship of stock returns, inflation, interest rates and real economic activity. The sample consists of four Latin American countries from January of 1995 to December of 2005. Our results indicate heterogeneous patterns for the relationship of financial and economic variables across countries. We also show that monetary policy shocks seem to affect Latin American stock markets. That evidence is rather weak, though. On the other hand, there is no significant relationship between stock markets and real activity and inflation.
\end{abstract}

Keywords: vector autoregression, dynamic relationships, stock market.

Received in 12/29/2007; revised in 03/02/2008; accept in 04/19/2008.

Corresponding authors:

+ Professor at the IBMEC-SP

Rua Quata, 300, Vila Olímpia,

Sao Paulo, SS, Brazil,

CEP 04546-042

e-mail: euriltona@isp.edu.br
IBMEC-SP

Rua Quata, 300, Vila Olímpia,

Sao Paulo, SS, Brazil,

CEP 04546-042

e-mail:felipeasb@hotmail.com

Editor's note: This paper was accepted by Alexsandro Broedel Lopes. 


\section{INTRODUCTION}

$\mathrm{T}$

The relationship of stock returns to macroeconomic variables is a recurring theme in the financial literature. However, few studies have focused on Latin America. Therefore, the objective of this work is to examine the relationship between stock

returns and macroeconomic variables through the specification and analysis of autoregressive vectors, extending the article of Lee (1992) to a sample of Latin American countries, as Canova \& De Nicoló (1997) did for the United States, United Kingdom, Japan and Germany. The aim is to understand how macroeconomic variables affect stock returns in important Latin American countries.

The countries investigated are Brazil, Chile, Mexico and Argentina. These countries have the best established stock markets in Latin America (Chen et al., 2002). Besides this, they export similar commodities, have significant trade and substantial mutual investments.

The variables used are inflation, stock return, interest rate and economic activity. We decided not to use the exchange rate for several reasons. First, the focus of this work is more on the domestic macroeconomic conditions of each country and not the interrelationship in terms of capital flows or international trade. Second, the inclusion of an additional variable would greatly increase the number of parameters to be estimated, compromising any type of inference. We believe that the analysis of the role of international capital flows and relationship between the foreign exchange market and stock market is should be the theme of another study, so we concentrated on the variables mentioned in the title of this work.

We conclude that there is a pattern in the relationship of these variables that is valid for all the countries. Besides this, the relation between the macroeconomic variables and stock returns is weak. There is some evidence of a relationship between interest rates and stock returns, but even this evidence is not robust.

This study is organized as follows: Section 2 summarizes the relevant literature; Section 3 analyzes the data used in the empirical study; Section 4 details the empirical model; Section 5 presents and discusses the results; and Section 6 concludes.

\section{REVIEW OF THE LITERATURE}

This section summarizes the results obtained by other similar studies. We cover a good number of relevant articles. However, to the best of our knowledge, there are no similar studies of Latin American countries.

Geske \& Roll (1983) studied the relation between stock returns and macroeconomic variables in the United States. Their results showed a negative relation between stock returns and inflation. The results of their study are consistent with the hypothesis of Fama (1981). For Fama, the negative relation between stock returns and inflation is not one of causality, but rather a proxy for the positive relationship between stock returns and real economic variables.

Darrat \& Mukherjee (1986) studied the causality relations between stock returns and some macroeconomic variables (money supply, short- and long-term interest rate, a proxy for aggregate demand and inflation rates) for the Indian market between 1948 and 1984. The authors analyzed the information efficiency of the financial market in semi-strong form, which according to Fama (1970) occurs if the current asset prices reflect not only the past asset prices, but also all the relevant public information. The results found indicate there is a significant lag between stock returns and growth of the money supply, thus denoting an 
information inefficiency of the market. Another result indicated that the long-term interest rate has a strong negative impact on stock returns, suggesting that the participants in the Indian market see long-term bonds and shares as being rough substitutes. Finally, a last result showed that inflation exercises some negative effect on stock returns, indicating that shares are not good protection against inflation.

Lee (1992) investigated the causality relations and dynamic interactions of stock returns, interest rates, real activity and inflation in the postwar United States (from January 1947 to December 1987), using a vector autoregressive (VAR) model. The results found were compatible with the explanation of Fama (1981) for the negative relation between stock returns and inflation. Besides this, no causal link was found between growth of the money supply and stock returns, and hence between inflation and stock returns.

Mukherjee \& Naka (1995) investigated the causality relations between the Tokyo Stock Exchange (TSE) index and six macroeconomic variables (exchange rate, money supply, inflation, industrial output, long-term interest rate on government bonds and call money rate), using the VECM methodology developed by Johansen (1991). The results showed a negative relation between the TSE index and both the inflation rate and long-term interest rate on government bonds. The other variables did not show a positive correlation.

Jones \& Kaul (1996) analyzed the relations between the price of oil and stock returns in the United States, Japan, Canada and United Kingdom during the post-war period. The relation between the oil price and real cash flow variables permits testing whether global stock markets are rational or overreact irrationally to a new piece of information. The results obtained led the authors to conclude that the American and Canadian markets are rational, responding to oil shocks and fully computing the impact current and future cash flow. However, the evidence for Japan and the United Kingdom was intriguing, in that the results for the two countries were not able to explain the effects of oil price shocks on the stock returns using changes in future cash flows.

Canova \& De Nicoló (1997) analyzed the relations of interdependence between stock returns, the interest rate term structure, inflation and industrial output for the United States, Germany, Japan and United Kingdom between January 1973 and December 1993. The authors used the VAR methodology, based on the assertion that it is appropriate to study the interdependence and transmission mechanisms of shocks in the financial markets and the economy. The results for the United States showed that stock returns are significantly and negatively related to inflation, and the term structure predicts the inflation rate. For the United Kingdom and Germany, the authors found a negative relation between stock returns and inflation, while for Japan they found that the term structure is significantly related to industrial output and inflation. Besides this, they found a negative relationship between stock returns and the level of economic activity. Finally, in general their results were heterogeneous among the countries.

Najand \& Noronha (1998) also investigated the causality relations of stock returns, interest rate, inflation and economic activity for the Japanese economy. The results indicate that inflation in the Granger sense causes negative variations in stock returns, ratifying the hypothesis of Fama (1981) that inflation predicts the variations in real activity and the interest rate. These results are consistent with those of Balduzzi (1995), but contrast with those obtained by Lee (1992) for the American market.

Naka et al. (1998), also employing the VECM methodology, investigated the longterm relations between the Indian stock market (Bombay Stock Exchange - BSE) and the following macroeconomic variables: industrial production index; consumer price index; M1; and interest rate. According to the authors, industrial output is an important positive 
determinant of share prices, while the inflation rate is an important negative determinant of those prices.

Granger et al. (1998) tested the direction of causality of the exchange rate on stock returns of nine countries (Hong Kong, Indonesia, Japan, South Korea, Malaysia, Philippines, Singapore, Thailand and Taiwan) after the Asian crisis. Another study analyzing the causality relations between stock returns and the exchange rate was that of Ajayi et al. (1998), who found one-way causality, in the Granger sense, i.e., stock returns cause the exchange rate in all developed countries studied (Canada, United Kingdom, Japan, Italy, France and Germany), while in the emerging economies (Hong Kong, Indonesia, South Korea, Malaysia, Philippines, Singapore, Thailand and Taiwan) no consistent relations were found between the variables. According to Ajayi et al. (1998), the differences found between the developed and emerging countries result from the structural differences between the two groups studied, where the markets of the emerging countries are smaller, more concentrated and less accessible to investors.

Know \& Shin (1999) analyzed whether the current level of economic activity can explain the variations in the Korean stock index, taking as a basis the response of asset prices in relation to macroeconomic variations, using the Granger causality test. The set of macroeconomic variables selected (production index, exchange rate, trade balance and money supply) is closely related to the Korean economy, which closely depends on international trade factors. Nevertheless, according to the authors, the most important discovery involves the perception of Korean investors with regard to stock price movements, which are totally different from those of American and Japanese investors, suggesting that the Korean market is more sensitive to international trading activity than to inflation rates of interest rates. According to Know \& Shin (1999), although the two-way causality between the stock index and output index in general, the stock index is not the main indicator of the economic variables. This is inconsistent with the results of Fama (1991), namely that the stock market rationally varies with the changing signal presented by the level of real activity.

Gjerde \& Saettem (1999) investigated the causality relations between stock returns and macroeconomic variables for the Norwegian economy, using VARs, as in Lee (1992). The results showed that the interest rate plays an important role in the Norwegian economy. More specifically, they found that the interest rate affects both stock returns and inflation. According to the authors, the Norwegian market is highly dependent on the price of oil, and this dependence is reflected in the stock market, which responds rationally to the variations in the oil price, i.e., the relation between the oil price and share prices is positive. Stock returns also respond positively to changes in industrial output, but this occurs with a lag, indicating some degree of inefficiency.

Gjerde \& Saettem (1999), Jarvinen (2000) and Hondroyiannis \& Papapetrou (2001) all employed VARs to analyze the dynamic relation between a set of macroeconomic variables (interest rate, oil price, industrial output and exchange rate) and stock returns in the Greek market. The analysis of the impulse response indicates that all the macroeconomic variables are important in explaining the movements in stock returns. The growth of industrial production responds negatively to shocks from stock returns, that is, an increase in the stock market does not necessarily lead to a higher level of industrial output. The stock returns also respond negatively to interest rate shocks, while an exchange rate depreciation leads to higher stock returns. They also found that a variation in the price of oil plays an important role in explaining stock price movements, and finally, that when the oil price goes up, there is a fall in stock prices. 
Maysami \& Koh (2000) studied the long-term equilibrium relations between selected macroeconomic variables and the Singapore stock market index, and also the relations among the stock indexes in Singapore, the United States and Japan. They used the VECM, the same employed by Mukherjee \& Naka (1995) and Naka et al. (1998). The results suggest that the Singapore stock market is sensitive to the interest rate and exchange rate. Additionally, the results show that the Singapore stock market index is significantly and positively cointegrated with those in the United States and Japan.

Neih \& Lee (2001), also employing the VECM model, analyzed the relations between the exchange rate and stock prices of the G7 countries. Their results indicate there is no significant long-term relationship between these variables, a result also obtained by BahmaniOskooe \& Sohrabian (1992), but unlike those of some other studies, which suggest there is a significant relationship between these two variables.

Perales \& Robins (2002) analyzed the relations between Mexican stock returns and economic variables, using the methodology proposed by Granger (1969). The results show that the IPC (the BMV index) is the main indicator of real future economic activity and that the behavior of M1 (money supply) is exercises an important influence on the IPC and industrial production index.

Bhattacharya \& Mukherjee (2003) empirically tested the causal relationship between the Indian stock market, using as a proxy the BSE Sensitive Index of the Bombay Stock Exchange, with selected macroeconomic variables (real exchange rate, foreign reserves and trade balance value). The results show there is no causality relation between the BSE Sensitive Index and the macroeconomic variables. Therefore, the market is said to be information efficient in the semi-strong sense, that is, the available public information is already reflected in the price of shares.

Nunes et al. (2002) examined the relations the São Paulo Stock Exchange Index (Ibovespa) in Brazil and two macroeconomic variables, industrial output (indicated by real GDP) and the real exchange rate, besides using the spreads between Brazilian government bonds placed abroad (C Bonds) and American Treasuries, with the intent of capturing the "Brazil risk" perceptions of investors. The authors utilized the cointegration test, Granger causality and error correction models, for the period between January 1995 and December 2001. The results indicate there is a long-term relationship among the variables studied. They also found a one-way causal relationship between the Ibovespa to the real exchange rate, which was not found when studying the relation between the Ibovespa and real GDP, demonstrating an inconsistency with the hypothesis that the Brazilian stock market signals variations in real activity. The Granger causality test between the Ibovespa and risk factor, using monthly data, indicated an absence of causality. When using daily data, the causality was two-way, evidencing a very short-range relationship between the financial series.

All these works seek to understand how the financial market responds to macroeconomic variations. However, each of them in general focused only on once country or did not seek to compare behavior patterns among countries.

\section{DATABASE}

This section presents some statistical characteristics of the data gathered for the present study. The variables utilized in this study are described in Table 1. 
Table 1: Basic Variables

\begin{tabular}{|c|c|c|c|c|c|}
\hline Países & Variáveis & Séries originais & Fontes & Outras informações & $\begin{array}{c}\text { Transformações } \\
\text { necessárias }\end{array}$ \\
\hline
\end{tabular}

\begin{tabular}{|c|c|c|c|c|c|}
\hline \multirow[t]{4}{*}{ Brasil } & Inflação & Taxa de inflação & $\begin{array}{l}\text { Instituto Brasileiro de } \\
\text { Geografia e Estatística }\end{array}$ & $\%$ mês & \\
\hline & Retorno acionário & $\begin{array}{l}\text { Indice do mercado acionário } \\
\text { (IBOVESPA) }\end{array}$ & Economatica & $\begin{array}{l}\text { Fechamento final de } \\
\text { mês }\end{array}$ & RETit=(SMlit/SMlit-1)* \\
\hline & Juros & Taxa de juros & Banco Central do Brasil & $\%$ mês & \\
\hline & Atividade econômica & Produção industrial em nível & $\begin{array}{l}\text { Instituto Brasileiro de } \\
\text { Geografia e Estatística }\end{array}$ & $2002=100$ & dlog \\
\hline
\end{tabular}

\begin{tabular}{|c|c|c|c|c|c|}
\hline \multirow[t]{4}{*}{ Argentina } & Inflação & Índice de Preço & \begin{tabular}{|l|} 
Instituto Nacional de \\
Estadística y Censos
\end{tabular} & $1999=100$ & dlog \\
\hline & Retorno acionário & $\begin{array}{l}\text { Índice do mercado acionário } \\
\text { (Merval) }\end{array}$ & Economatica & $\begin{array}{l}\begin{array}{l}\text { Fechamento final de } \\
\text { mês }\end{array} \\
\end{array}$ & RETit=(SMlitSMlit-1) ${ }^{*}$ \\
\hline & Juros & Juros & $\begin{array}{l}\text { Banco Central de la } \\
\text { República Argentina } \\
\end{array}$ & $\%$ ano & \\
\hline & Atividade econômica & Produção industrial em nível & $\begin{array}{l}\text { Instituto Nacional de } \\
\text { Estadística y Censos }\end{array}$ & $1997=100$ & dlog \\
\hline
\end{tabular}

\begin{tabular}{|c|c|c|c|c|c|}
\hline \multirow[t]{4}{*}{ Chile } & Inflação & Índice de Preço & $\begin{array}{l}\text { Instituto Nacional de } \\
\text { Estadísticas }\end{array}$ & $1998=100$ & dlog \\
\hline & Retorno acionário & $\begin{array}{l}\text { Índice do mercado acionário } \\
\text { (IGPA) }\end{array}$ & Economatica & $\begin{array}{l}\text { Fechamento final de } \\
\text { mês }\end{array}$ & RETit=(SMlit/SMlit-1)* \\
\hline & Juros & Juros & Banco Central de Chile & $\%$ ano & \\
\hline & Atividade econômic & $\begin{array}{l}\text { Crescimento da produção } \\
\text { industrial }\end{array}$ & $\begin{array}{l}\text { Instituto Nacional de } \\
\text { Estadísticas }\end{array}$ & $\%$ mês & \\
\hline
\end{tabular}

\begin{tabular}{|c|c|c|c|c|c|}
\hline \multirow[t]{4}{*}{ México } & Inflação & Taxa de inflação & Banco de Mexico & $\%$ mês & \\
\hline & Retorno acionário & $\begin{array}{l}\text { Indice do mercado acionário } \\
(\mathrm{IPyC})\end{array}$ & Economatica & $\begin{array}{l}\text { Fechamento final de } \\
\text { mês }\end{array}$ & RETit=(SMlit/SMlit-1 $)^{*}$ \\
\hline & Juros & Juros & Banco de Mexico & $\%$ ano & \\
\hline & Atividade econômica & Produção industrial em nível & $\begin{array}{l}\text { Instituto Nacional de } \\
\text { Geografía e Informática }\end{array}$ & $1993=100$ & dlog \\
\hline
\end{tabular}

* RETit é taxa nominal de retorno do mercado acionário e SMlit é o índice do mercado acionário (fechamento) para o período t no país i em moeda local. 
Table 2 shows the period covered by the data for each country and their descriptive statistics.

Table 2: Descriptive Statistics

\begin{tabular}{|c|c|c|c|c|c|c|c|c|c|c|c|}
\hline Paises & $\begin{array}{c}\text { Séries } \\
\text { transformada }\end{array}$ & Unidades & Períodos & $\begin{array}{c}\text { No. } \\
\text { observações }\end{array}$ & Média & Mediana & Máximo & Mínimo & $\begin{array}{l}\text { Desvio } \\
\text { Padrão } \\
\end{array}$ & Assimetria & Curtose \\
\hline \multirow[t]{4}{*}{ Brasil } & Taxa de inflação & $\%$ mês & jan-95 a dez-05 & 131 & 0,6889 & 0,5600 & 3,0200 & $-0,5100$ & 0,5905 & 1,4288 & 5,6733 \\
\hline & \begin{tabular}{|l|} 
Taxa nominal de \\
retorno do \\
mercado acionário \\
Tana
\end{tabular} & $\%$ mês & jan-95 a dez-05 & 131 & $\frac{0,0220}{1.0202}$ & 0,0299 & 0,2802 & $-0,3955$ & 0,1027 & $-0,5855$ & 4,4540 \\
\hline & Taxa de juros & $\%$ mês & jan-95 a dez-05 & 131 & 1,8262 & 1,5903 & \begin{tabular}{|l|}
4,2621 \\
\end{tabular} & 1,0158 & 0,7080 & 1,8722 & 6,1275 \\
\hline & \begin{tabular}{|l|} 
Taxa de \\
crescimento da \\
produção industrial
\end{tabular} & $\%$ mês & jan-95 a dez-05 & 131 & 0,0018 & $-0,0042$ & 0,1749 & $-0,1392$ & 0,0639 & 0,2384 & 3,2683 \\
\hline \multirow[t]{3}{*}{ Chile } & Taxa de inflação & $\%$ mês & jan-95 a dez-05 & 131 & 0,0033 & 0,0034 & \begin{tabular}{l|l|}
0,0163 \\
\end{tabular} & $-0,0044$ & 0,0037 & 0,2437 & 3,4564 \\
\hline & \begin{tabular}{|l|} 
Taxa nominal de \\
retorno do \\
mercado acionário
\end{tabular} & 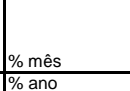 & $\mid \begin{array}{l}\text { jan-95 a dez-05 } \\
\text { jan-95 a dez-05 }\end{array}$ & $\frac{131}{131}$ & $\frac{0,0052}{5,2260}$ & $\frac{0,0009}{5,3700}$ & \begin{tabular}{r|}
0,1664 \\
12,7600
\end{tabular} & $\begin{array}{c}-0,2088 \\
1,7500\end{array}$ & $\frac{0,0470}{2,1767}$ & 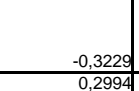 & $\frac{6,2460}{2,9349}$ \\
\hline & \begin{tabular}{|l|} 
Taxa de \\
crescimento da \\
produção industrial
\end{tabular} & $\%$ mês & jan-95 a dez-05 & 131 & 0,5775 & $-1,1073$ & 24,0882 & $-13,7491$ & 7,8414 & 0,8838 & 3,4363 \\
\hline \multirow[t]{3}{*}{ Mexico } & Taxa de inflação & $\%$ mês & jan-95 a dez-05 & 131 & 1,0542 & 0,7200 & 7,9700 & $-0,3200$ & 1,1488 & 2,8010 & 14,3017 \\
\hline & $\begin{array}{l}\text { Taxa nominal de } \\
\text { retorno do } \\
\text { mercado acionário } \\
\end{array}$ & $\%$ mês & jan-95 a dez-05 & $\frac{131}{131}$ & \begin{tabular}{r|}
0,0198 \\
20029
\end{tabular} & 0,0281 & 0,1932 & $-0,2952$ & 0,0809 & $-0,6661$ & 4,5739 \\
\hline & $\begin{array}{l}\text { Taxa de } \\
\text { crescimento da } \\
\text { produção industrial }\end{array}$ & $\%$ mês & jan-95 a dez-05 & 131 & 0,0025 & $-0,0048$ & 0,1038 & $-0,1058$ & 0,0397 & 0,3233 & 3,1188 \\
\hline \multirow[t]{4}{*}{ Argentina } & Taxa de inflação & \% mês & jan-95 a dez-05 & 130 & 0,0041 & 0,0016 & \begin{tabular}{|l|}
0,0988 \\
\end{tabular} & $-0,0075$ & 0,0118 & 4,7835 & 34,7494 \\
\hline & $\begin{array}{l}\text { Taxa nominal de } \\
\text { retorno do } \\
\text { mercado acionário }\end{array}$ & $\%$ mês & jan-95 a dez-05 & 130 & 0,0133 & 0,0226 & 0,4868 & $-0,3911$ & 0,1133 & 0,1910 & 5,7898 \\
\hline & Taxa de juros & $\%$ ano & jan-95 a dez-05 & 130 & 10,6235 & 6,6150 & 91,1900 & 1,2000 & 14,8810 & 3,4699 & 15,4537 \\
\hline & \begin{tabular}{|l} 
Taxa de \\
crescimento da \\
produção industrial
\end{tabular} & $\%$ mês & jan-95 a dez-05 & 130 & 0,0033 & $-0,0028$ & 0,1366 & $-0,1380$ & 0,0532 & 0,3385 & \\
\hline
\end{tabular}

The sample used is formed of monthly data from January 1995 to December 2005. The reason for choosing monthly date was to maximize the number of observations available for estimation.

According to the data presented in Table 2, the inflation and interest rates reached the highest levels in Mexico, and also were the most volatile in that country. And unlike would be expected, the stock returns were less volatile than the interest rates in all the countries. Finally, the excess kurtosis and asymmetry present in some of the series suggest non-normal distributions.

Table 3 depicts the correlation pattern between each of the variables in each country. The domestic cross correlations suggest a weak negative correlation of the variables, except for Mexican and Brazilian interest rates and inflation, which are positively related. Besides this, the growth rates of industrial output and interest rates for Argentina are also positively related. 
Table 3: Domestic Cross Correlations

\begin{tabular}{|c|c|c|c|c|c|}
\hline \multirow{1}{*}{ Brasil } & $\begin{array}{c}\text { Taxa de } \\
\text { crescimento da } \\
\text { produção industrial }\end{array}$ & Taxa de inflação & Taxa de juros & $\begin{array}{c}\text { Taxa nominal de } \\
\text { retorno do mercado } \\
\text { acionário }\end{array}$ \\
\cline { 2 - 6 } & $\begin{array}{c}\text { Taxa de } \\
\text { crescimento da } \\
\text { produção industrial }\end{array}$ & 1,0000 & $-0,0456$ & $-0,0047$ & $-0,0522$ \\
\hline Taxa de inflação & $-0,0456$ & 1,0000 & 0,4564 & 0,1437 \\
\hline Taxa de juros & $-0,0047$ & 0,4564 & 1,0000 & 0,1385 \\
\cline { 2 - 6 } & $\begin{array}{c}\text { Taxa nominal de } \\
\text { retorno do } \\
\text { mercado acionário }\end{array}$ & $-0,0522$ & 0,1437 & & 0,1385 \\
\end{tabular}

\begin{tabular}{|c|c|c|c|c|c|}
\hline \multirow{5}{*}{ Chile } & $\begin{array}{c}\text { Taxa de } \\
\text { crescimento da } \\
\text { produção industrial }\end{array}$ & Taxa de inflação & Taxa de juros & $\begin{array}{c}\text { Taxa nominal de } \\
\text { retorno do mercado } \\
\text { acionário }\end{array}$ \\
\cline { 2 - 6 } & $\begin{array}{c}\text { Taxa de } \\
\text { crescimento da } \\
\text { produção industrial }\end{array}$ & 1,0000 & 0,2495 & $-0,1318$ & 0,1871 \\
\hline Taxa de inflação & 0,2495 & 1,0000 & $-0,1474$ & $-0,0227$ \\
\hline Taxa de juros & $-0,1318$ & $-0,1474$ & 1,0000 & 0,1414 \\
\cline { 2 - 6 } & $\begin{array}{c}\text { Taxa nominal de } \\
\text { retorno do } \\
\text { mercado acionário }\end{array}$ & 0,1871 & $-0,0227$ & & 0,1414 \\
\hline
\end{tabular}

\begin{tabular}{|c|c|c|c|c|c|}
\hline \multirow[t]{5}{*}{ Mexico } & & $\begin{array}{c}\text { Taxa de } \\
\text { crescimento da } \\
\text { produção industrial }\end{array}$ & Taxa de inflação & Taxa de juros & $\begin{array}{c}\text { Taxa nominal de } \\
\text { retorno do mercado } \\
\text { acionário }\end{array}$ \\
\hline & $\begin{array}{c}\text { Taxa de } \\
\text { crescimento da } \\
\text { produção industrial }\end{array}$ & 1,0000 & $-0,1139$ & $-0,0064$ & 0,1286 \\
\hline & Taxa de inflação & $-0,1139$ & 1,0000 & 0,9046 & 0,0870 \\
\hline & Taxa de juros & $-0,0064$ & 0,9046 & 1,0000 & 0,1170 \\
\hline & $\begin{array}{c}\text { Taxa nominal de } \\
\text { retorno do } \\
\text { mercado acionário }\end{array}$ & 0,1286 & 0,0870 & 0,1170 & 1,0000 \\
\hline
\end{tabular}

\begin{tabular}{|c|c|c|c|c|c|}
\hline \multirow{1}{*}{ Argentina } & $\begin{array}{c}\text { Taxa de } \\
\text { crescimento da } \\
\text { produção industrial }\end{array}$ & Taxa de inflação & Taxa de juros & $\begin{array}{c}\text { Taxa nominal de } \\
\text { retorno do mercado } \\
\text { acionário }\end{array}$ \\
\cline { 2 - 6 } & $\begin{array}{c}\text { Taxa de } \\
\text { crescimento da } \\
\text { produção industrial }\end{array}$ & 1,0000 & 0,0649 & 0,6602 & $-0,0049$ \\
\hline Taxa de inflação & 0,0649 & 1,0000 & 0,0671 & $-0,0645$ \\
\cline { 2 - 6 } & Taxa de juros & 0,6602 & 0,0671 & 1,0000 & $-0,1053$ \\
\cline { 2 - 6 } & $\begin{array}{c}\text { Taxa nominal de } \\
\text { retorno do } \\
\text { mercado acionário }\end{array}$ & $-0,0049$ & $-0,0645$ & & $-0,1053$ \\
\hline
\end{tabular}


We also examined the presence of a unit root in the series. The most formal way to do this is by the test developed by Fuller (1976), which was subsequently complemented by Dickey \& Fuller (1979 and 1981). We therefore used the augmented Dickey-Fuller test (ADF), with the usual specifications for the test, as follows:

$$
\begin{gathered}
\Delta Y_{t}=\gamma Y_{t-1}+\sum_{i=1}^{p-1} \delta_{i} \Delta Y_{t-i}+\varepsilon_{t} \\
\Delta Y_{t}=\alpha+\gamma Y_{t-1}+\sum_{i=1}^{p-1} \delta_{i} \Delta Y_{t-i}+\varepsilon_{t} \\
\Delta Y_{t}=\alpha+\beta t+\gamma Y_{t-1}+\sum_{i=1}^{p-1} \delta_{i} \Delta Y_{t-i}+\varepsilon_{t}
\end{gathered}
$$

The objective is to test the hypothesis $\gamma=0$. If the hypothesis is rejected, there is evidence of the presence of a unit root. To determine the number of lags to be included in the regressions above, we followed the general to the specific modeling, that is, we estimated (1), (2) and (3) including a very large number of lags and then eliminated them one by one if the coefficient of the last one was not significant, as suggested by Campbell \& Perron (1991). The statistical significance of the last lag together with the smaller values of the Akaike and Schwartz information criteria, and from the Ljung \& Box (1978) autocorrelation test, were the procedures followed to determine the ideal number of lags. A summary of the results obtained

\begin{tabular}{|c|c|c|c|c|}
\hline Paíse & Variáveis & Especificação & Resultados & $\begin{array}{c}\text { Nível de } \\
\text { significância }\end{array}$ \\
\hline \multirow[t]{4}{*}{ Brasil } & Inflação & com intercepto & rejeito & $5 \%$ \\
\hline & Juros & com intercepto & rejeito & 10 \\
\hline & Atividade econômica & nad & rejeito & $5 \%$ \\
\hline & Retorno acionário & com intercepto & rejeito & $5 \%$ \\
\hline \multirow[t]{4}{*}{ Argentina } & Inflação & nad & rejeito & $5 \%$ \\
\hline & Juros & com intercepto & rejeito & 10 \\
\hline & Atividade econômica & nad & rejeito & $5 \%$ \\
\hline & Retorno acionário & com intercepto & rejeito & $5 \%$ \\
\hline \multirow[t]{4}{*}{ Chile } & Inflação & intercepto e tendencia & rejeito & $5 \%$ \\
\hline & Juros & intercepto e tendencia & rejeito & 10 \\
\hline & Atividade econômica & com intercepto & rejeito & $5 \%$ \\
\hline & Retorno acionário & com intercepto & rejeito & $5 \%$ \\
\hline \multirow[t]{4}{*}{ México } & Inflação & intercepto e tendencia & rejeito & $5 \%$ \\
\hline & Juros & intercepto e tendencia & rejeito & 10 \\
\hline & Atividade econômica & intercepto e tendencia & rejeito & $5 \%$ \\
\hline & Retorno acionário & com intercepto & rejeito & $5 \%$ \\
\hline
\end{tabular}
are in the table below.

Table 4: Results of the ADF Test

The results show that for all the countries all the variables appear not to have a unit root, because the hypothesis $\gamma=0$ is rejected at 5\%, except for the interest rate, for which the hypothesis is rejected at $10 \%$.

\section{Empirical Methodology}

This work employs the vector autoregression (VAR) model to explore the relations among inflation, stock returns, interest rates and economic activity levels.

Models in reduced form involving stock returns, level of economic activity, inflation and interest rates have been examined by various authors, as seen in the literature review. This study maintains the same structure employed by Canova \& De Nicoló (1997), 
except for the use of the real interest rate instead of the interest rate term structure (yield curve), as done by Lee (1992).

In this work, we did not include the real exchange rate or variation in the nominal exchange rate, even though the economies studied are small open economies, for the following reasons. First, we wanted to maintain the focus on the domestic fundamentals of each country, which emphasizes the internal economic structure rather than the perception of external risks that are associated with capital flows, and consequently fluctuations in the exchange rate. Second, by including the exchange rate in the VAR, we would have had to include an external block with other variables, such as the current accounts, exports and imports, to analyze the transmission mechanism of external shocks. This would have hugely increased the number of estimated parameters, making a reliable analysis of the results impossible.

An important point in the study of a VAR is the order of the variables. In general, the order is relevant for impulse response and variance decomposition. For variance decomposition we report results associated with the following variable order: economic activity, interest rate, inflation and stock returns. However, we conducted a sensitivity analysis, not reported here, that shows that the results presented for the above variable order do not change significantly when the order of including the variables in the VAR changes. Additionally, we used generalized impulse response functions, which are independent of the order.

The number of lags, $p$, considered in vector autoregression models can be obtained in various ways, but in the present study we used information criteria along with autocorrelation tests for the residuals, which should be near white noise. The order of each VAR is presented in Table 5.

Table 5: Order of Lags

\begin{tabular}{|l|c|}
\hline País & Número de defasagens (meses) \\
\hline Brasil & 11 \\
\hline Chile & 11 \\
\hline Mexico & 8 \\
\hline Argentina & 5 \\
\hline
\end{tabular}

After determining the order of lags, $p$, and estimating the VAR, it was possible to study the response to shocks through the impulse response function, carry out the variance decomposition of the prediction error and evaluate the causality pattern, in the Granger sense, between the variables studied.

\section{Results}

\subsection{Impulse Responses}

Given that the order is important for the impulse response, we decided to report the generalized impulse response, which is independent of the order chosen. According to the impulse responses, for Brazil there is a small and initial effect of a unit shock of one standard deviation in the stock return (RET) on the interest rate $(\mathrm{R})$.

For Chile, the results found in this study were: the stock return (RET) falls slightly and initially with a unit shock of one standard deviation in inflation (PI). The interest rate (R) 
responds positively to the level of economic activity (Y) over a horizon of six to seven months months, and also responds to inflation (PI).

In the case of Mexico, the results are: inflation (PI) rises slightly after a unit shock of one standard deviation in the interest rate $(\mathrm{R})$, between the second and fourth month. The interest rate $(\mathrm{R})$ falls initially and for eight months after a unit shock of one standard deviation in the stock returns (RET).

The result found for Argentina is that the interest rate (R) falls, very little and initially, after a unit shock of one standard deviation in stock returns (RET).

A unit shock of one standard deviation in stock returns makes interest rates decline initially. This effect is statistically different than zero for Chile, Mexico and Argentina.

In general, many responses are such that zero is part of the range. Therefore, the empirical evidence based on impulse responses is quite fragile.

Figure 1: Generalized Impulse Response Function for Brazil

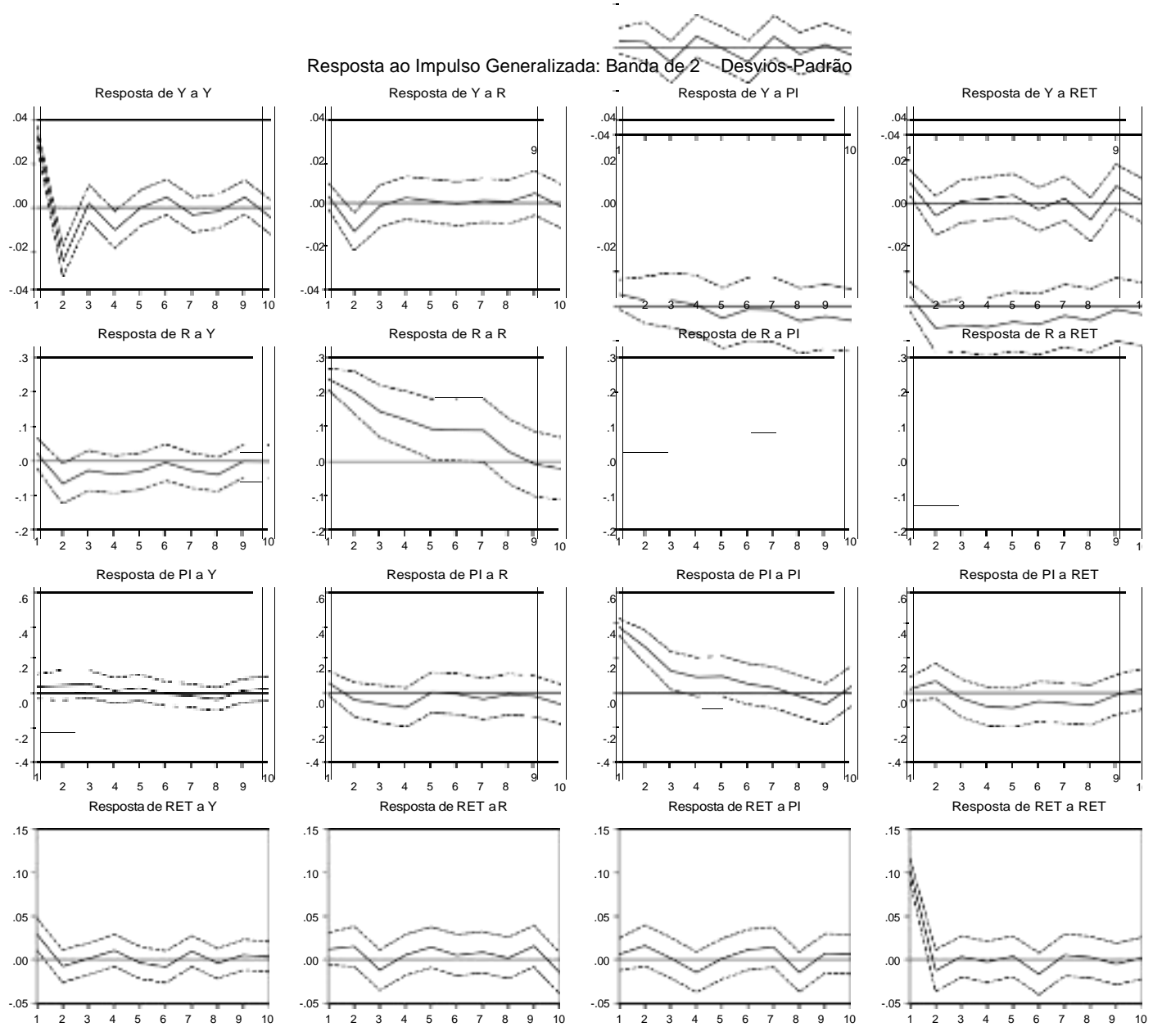


Figure 2: Generalized Impulse Response Function for Chile

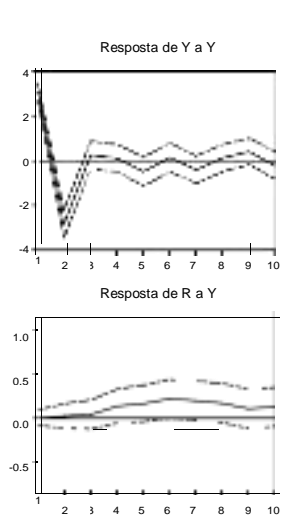

Resposta ao Impulso Generalizada: Banda de 2 Desvios-Padrão
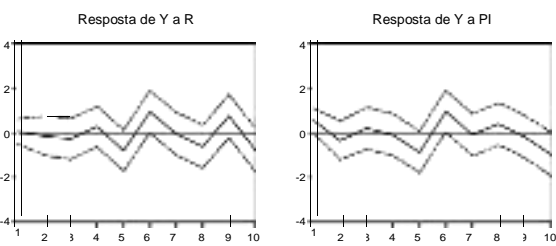

Resposta de R a R

Resposta de R a P
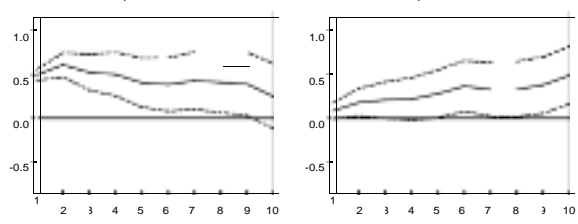

Resposta de Pla $\mathrm{Y}$

Resposta de Pl a PI
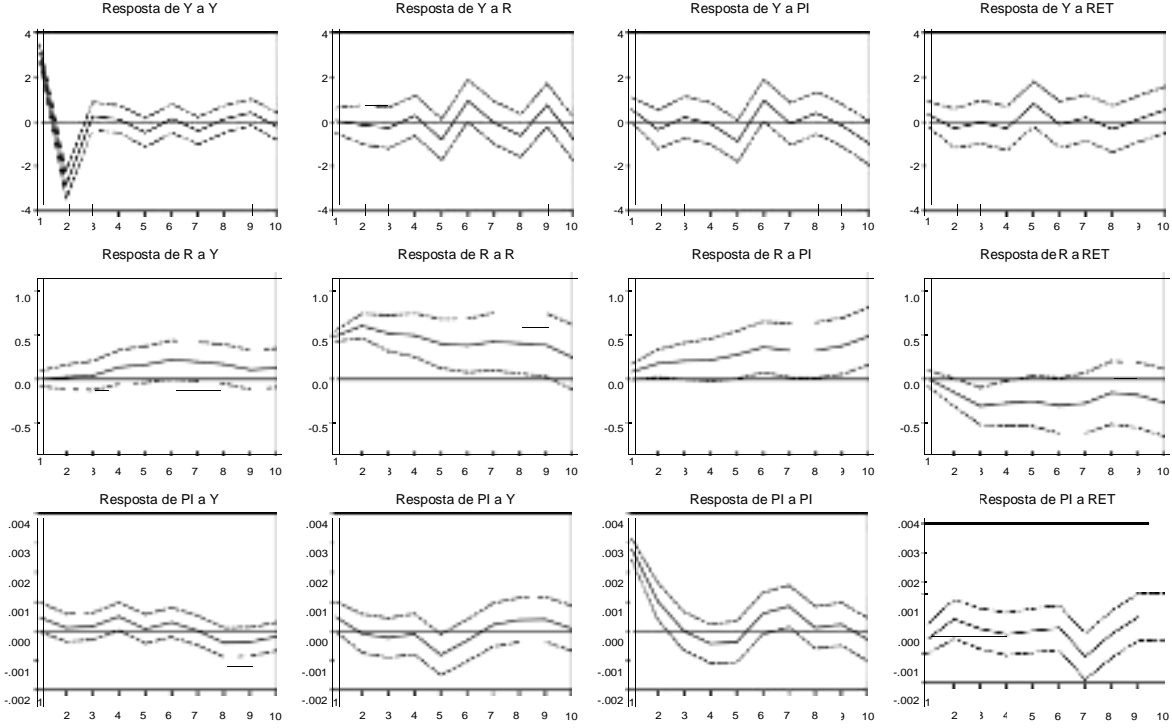

Resposta de RaRET

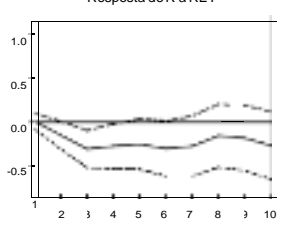

Resposta de Pl a RET
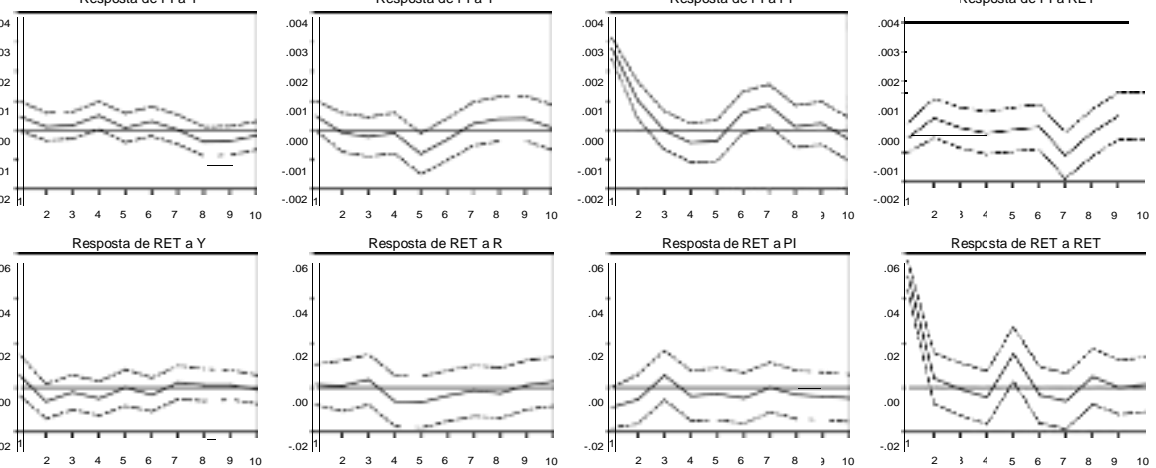

Figure 3: Generalized Impulse Response Function for Mexico

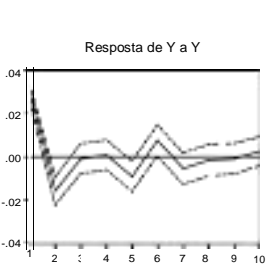

Resposta ao Impulso Generalizada: Bandas de 2 Desvios-Padrão
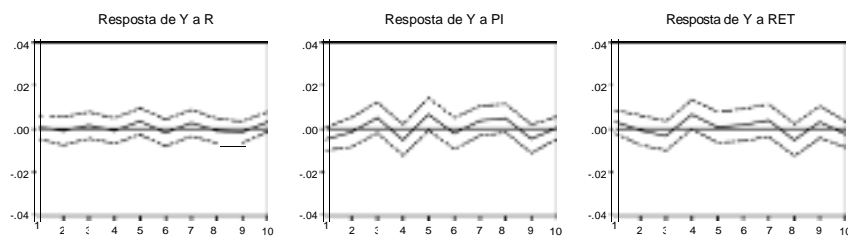

Resposta de R a Y

Resposta de Ra R

Resposta de R a PI
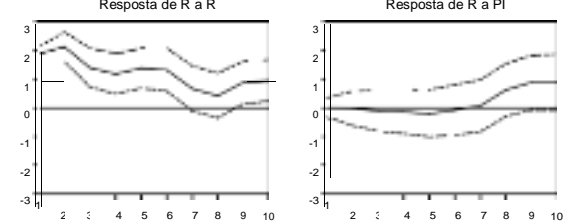

Respostade R a RET
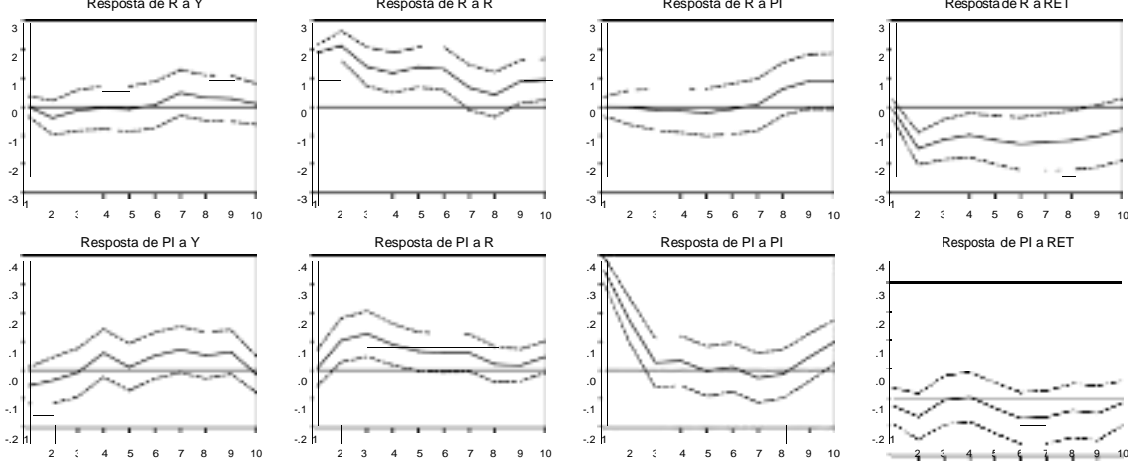

Resposta de Pl a RET
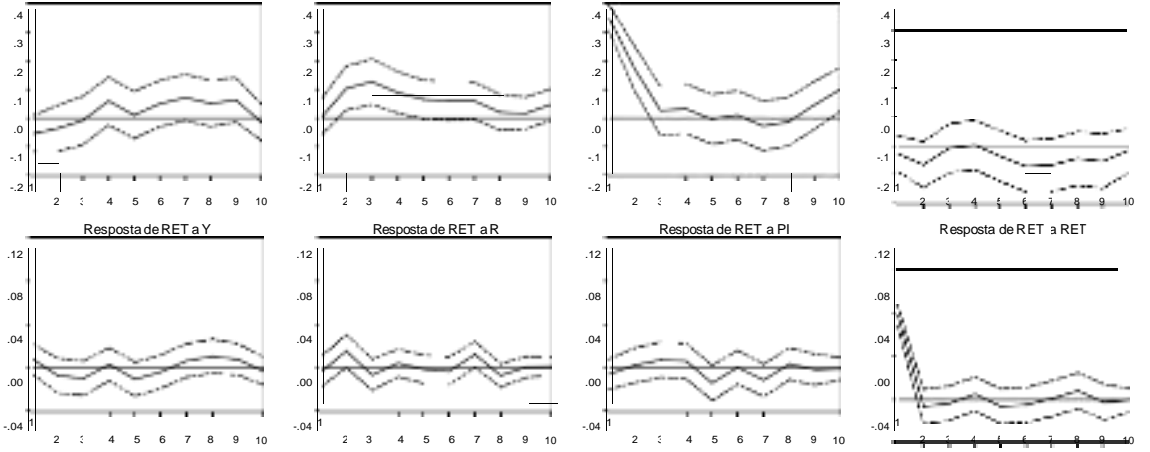
Figure 4: Generalized Impulse Response Function for Argentina

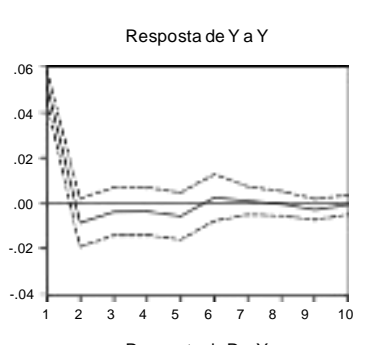

Resposta ao Impulso Generalizada: Bandas de 2 Desvios-Padrão
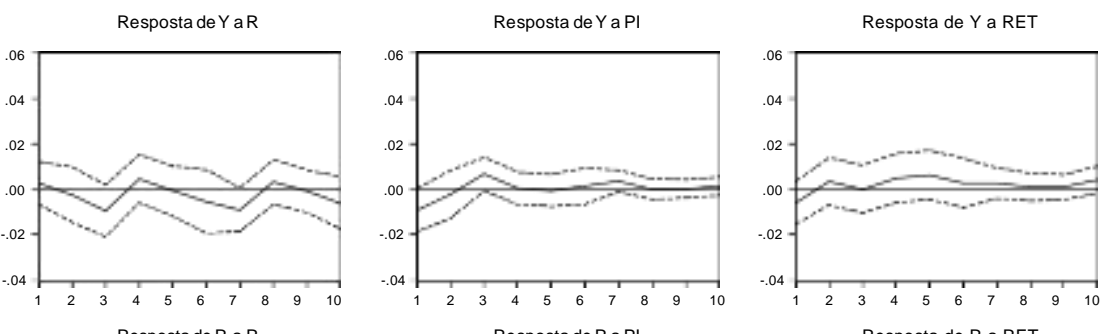

Respostade RaY

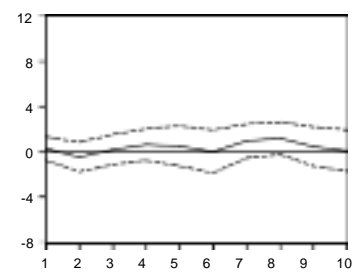

Respostade RaR

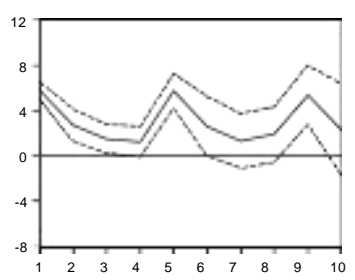

Respostade RaPI

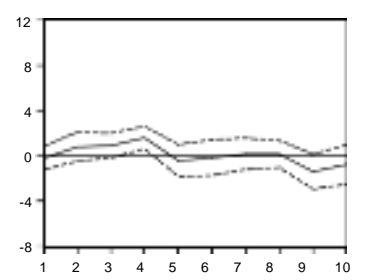

Resposta de R a RET

Resposta de PlaY

RespostadePlaR

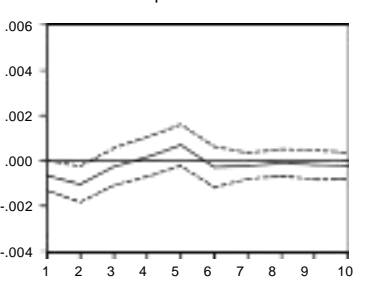

Resposta de RET aY

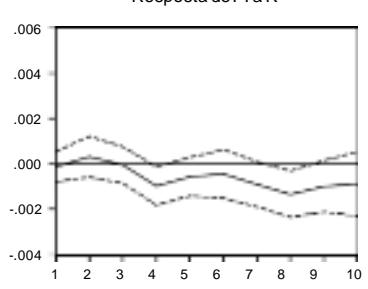

Resposta de PI a PI

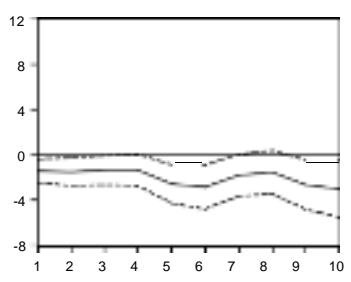

Resposta de PI a RET

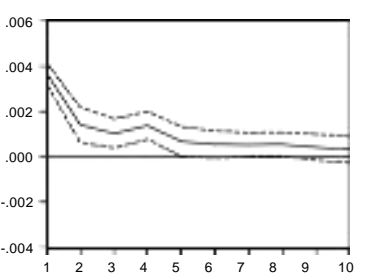

RespostadeRET aR

Resposta de RET a PI
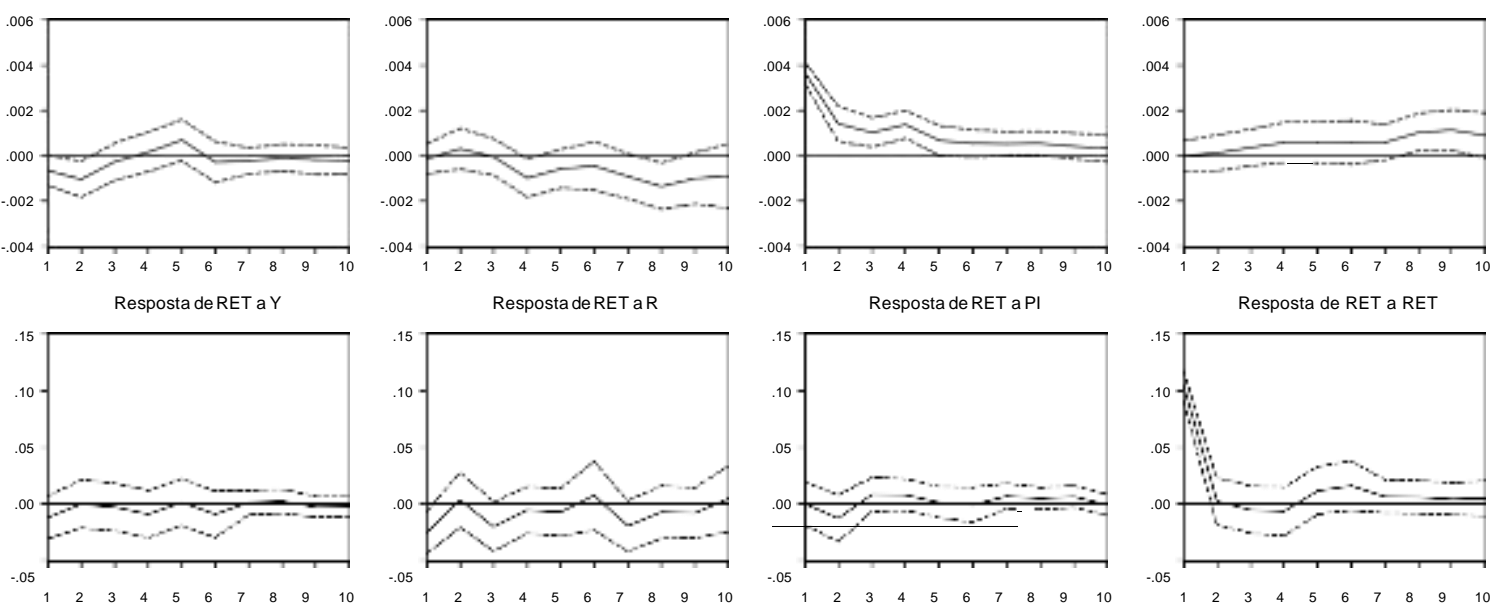

Resposta de RET a RET

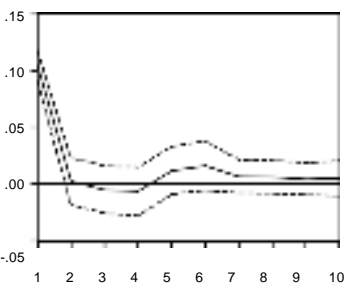

\subsection{Variance Decomposition}

We used the VAR model to evaluate the variance decomposition of the prediction errors $k$ periods ahead. The results are summarized in Figures 5 to 8, for a 24-month horizon.

In the Brazilian case, none of the variables chosen significantly explains the level of economic activity (Y), besides that variable itself. The level of activity (Y) explains the variance in interest rates (R) significantly, but with small magnitude. None of the variables chosen significantly explains inflation (PI) except that variable itself. The stock return (RET) is explained significantly by the level of activity (Y), but again with small magnitude.

The results for Chile show that none of the variables significantly explains the level of activity (Y) beyond the variable itself. Inflation (PI) significantly explains the interest rate (R) over longer horizons. None of the variables chosen explains inflation (PI) significantly except the variable itself. Also, none of the variables significantly explains the stock return (RET) except the variable itself.

The results for the Mexican economy show that none of the variables significantly explains the level of activity (Y) except the same variable. The stock return (RET) significantly explains the interest rate (PI), along with that same variable. Finally, none of the variables explains the stock return (RET) except that variable itself. 
The results for Argentina show that none of the variables is able to significantly explain the level of activity (Y) besides that same variable. The stock return (RET) significantly explains the interest rate $(\mathrm{R})$, while the interest rate $(\mathrm{R})$ and stock return (RET) both significantly explain inflation (PI). Finally, no variable explains the stock return (RET) except that variable itself.

Figure 5: Variance Decomposition for Brazil

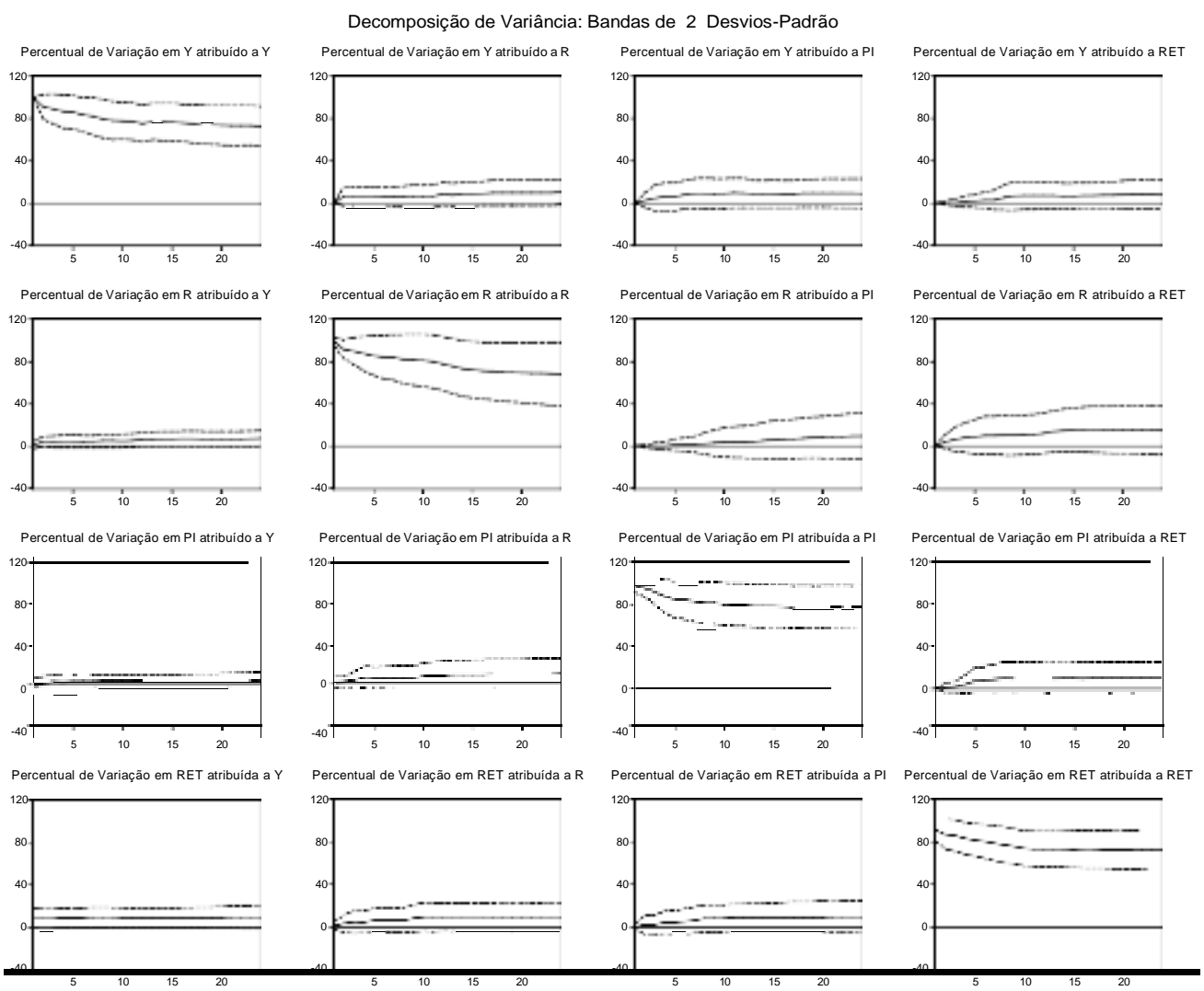




\section{Figure 6: Variance Decomposition for Chile}

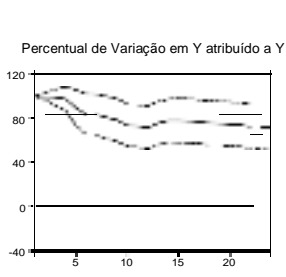

Decomposição de Variância: Banda de 2 Desvios-Padrão
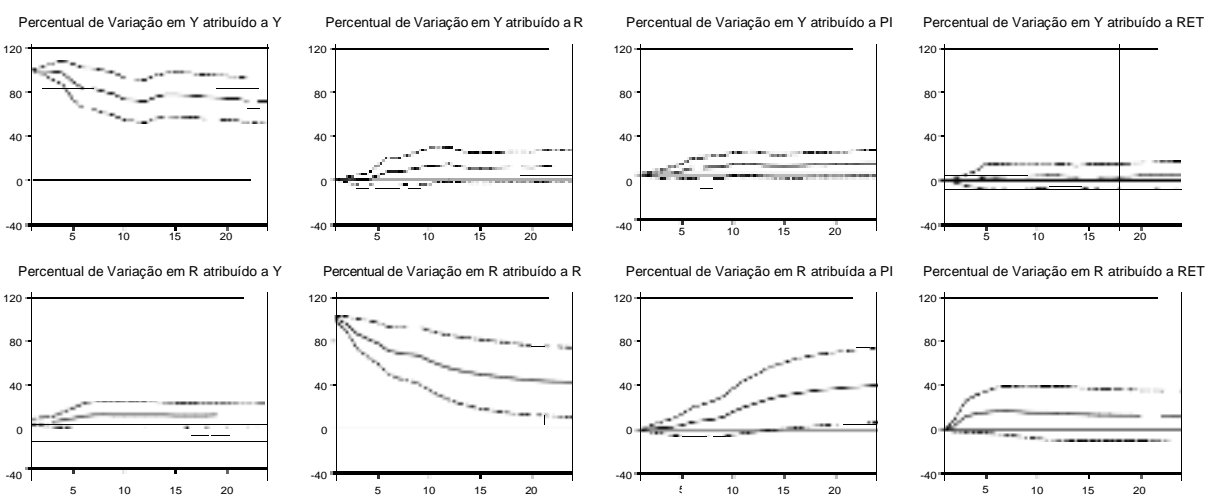

Percentual de Variação em $R$ atribuido a RET

Percentual de Variação em PI atribuida a

Percentual de Variação em PI atribuída a
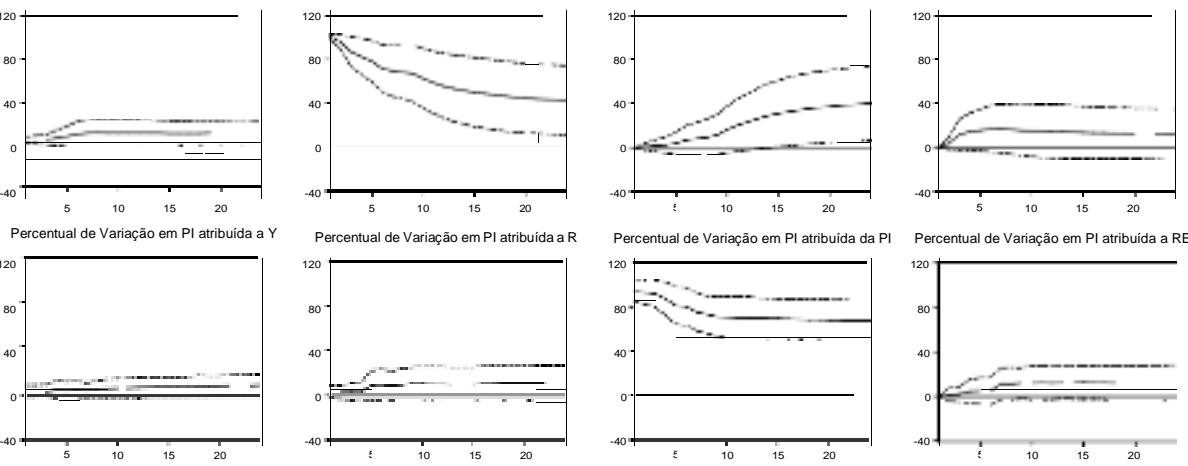

Percentual de Variação em RET atribuida a Y

Percentual de Variação em RET atribuida a R
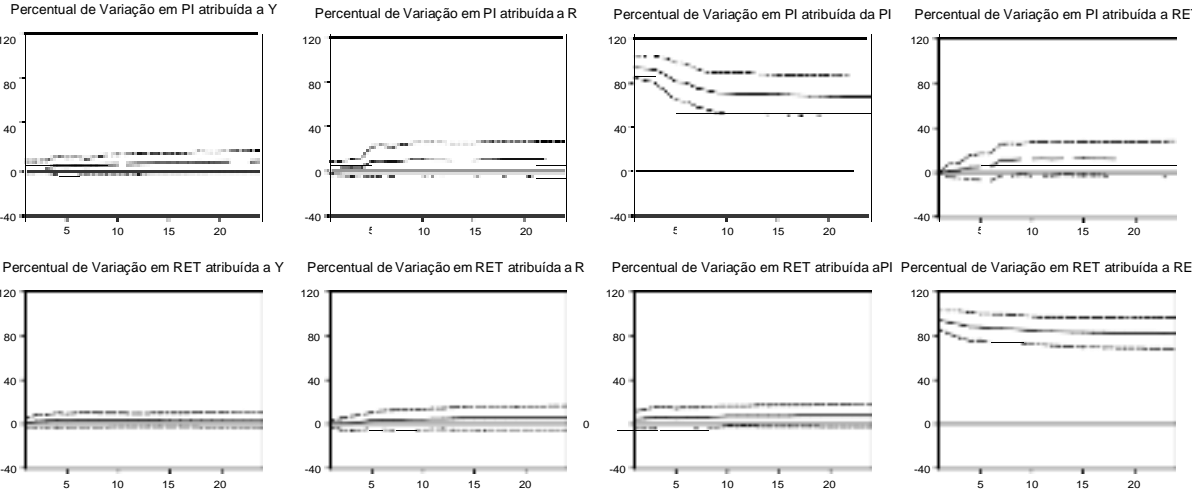

Figure 7: Variance Decomposition for Mexico

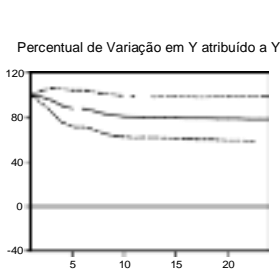

Decomposição de Variância:Banda de 2 Desvios-Padrão
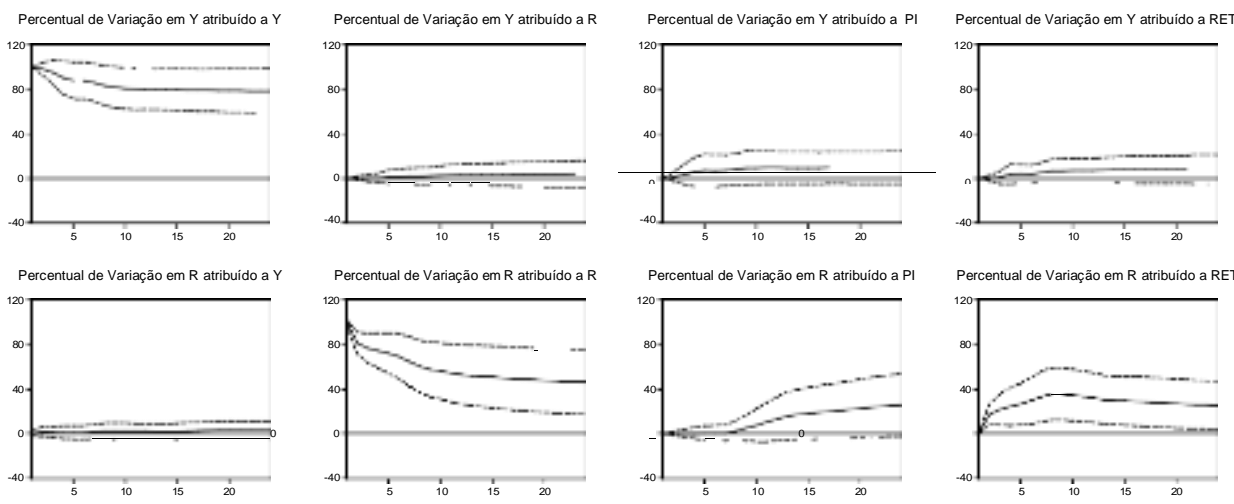

Percentual de Variação em Pl atribuido a Y
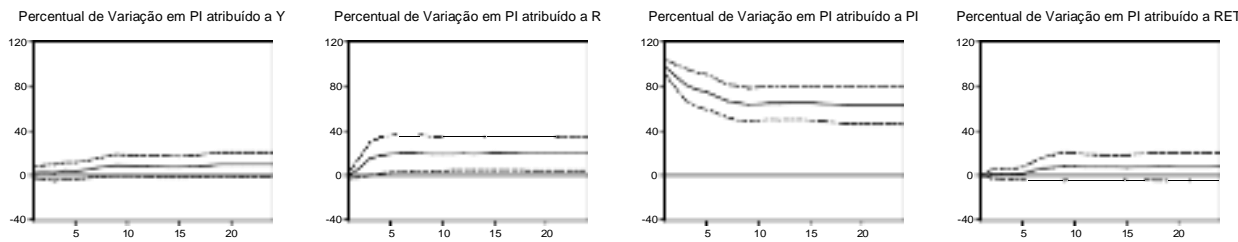

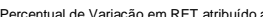

Percentual de Variação em RET atribuido a
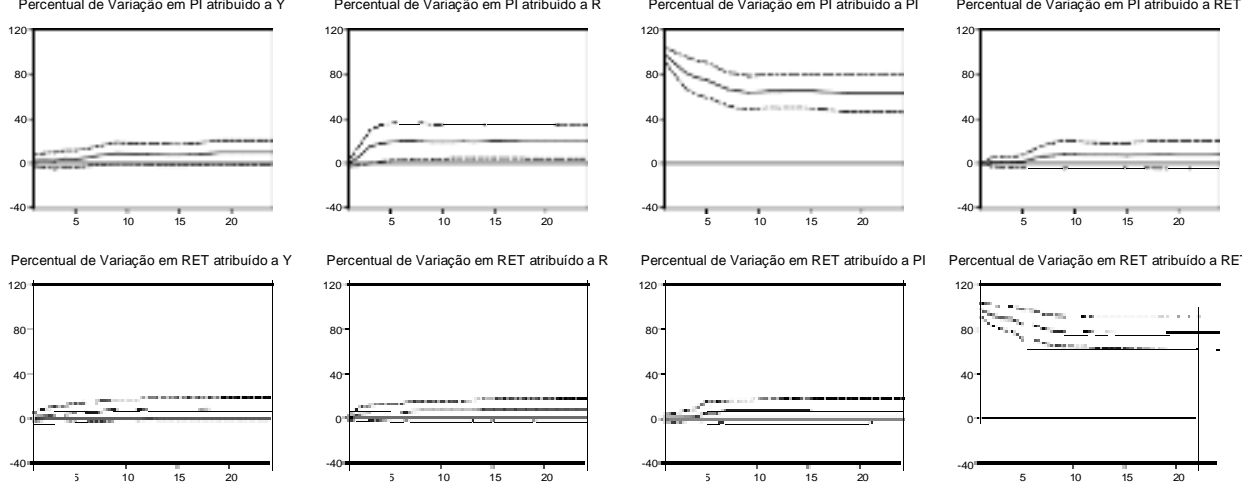
Figure 8: Variance Decomposition for Argentina

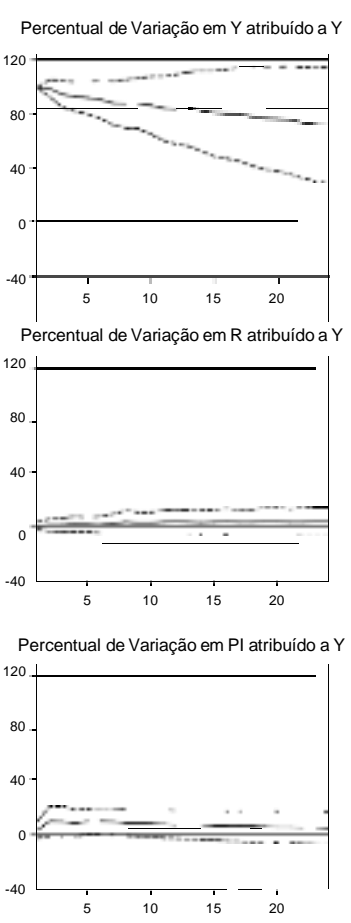

Decomposição de Variânica:Banda de 2 Desvios-Padrão
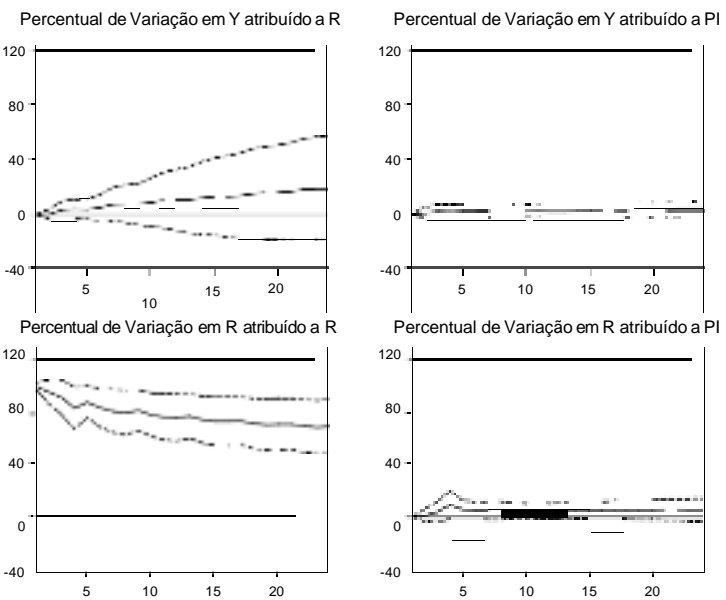

Percentual de Variação em Y atribuído a RET

Percentual de Variação em Y atribuído a Y

Percentual de Variaçãoem Pl atribuído a R

Percentual de Variação em PI atribuída a PI

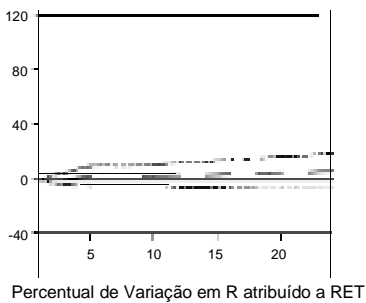

Percentual de Variação em R atribuído a RET
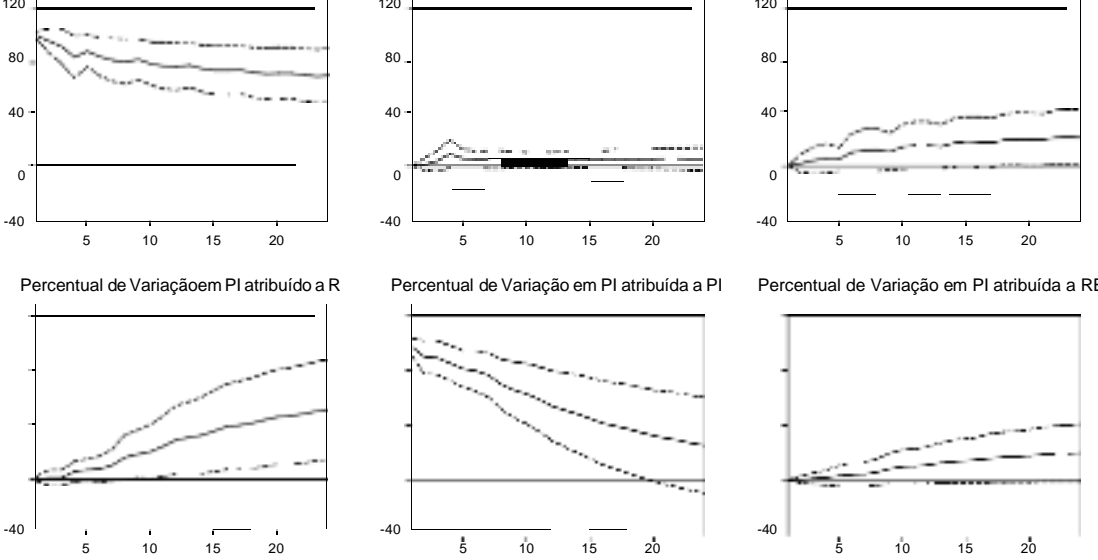

Percentual de Variação em PI atribuída a RET

Percentual de Variação em RET atribuída a Y

Percent de Variação em RET atribuído a R

Percentual de Variação em RET atribuído a PI Percentual de Variação em RET atribuído a RET
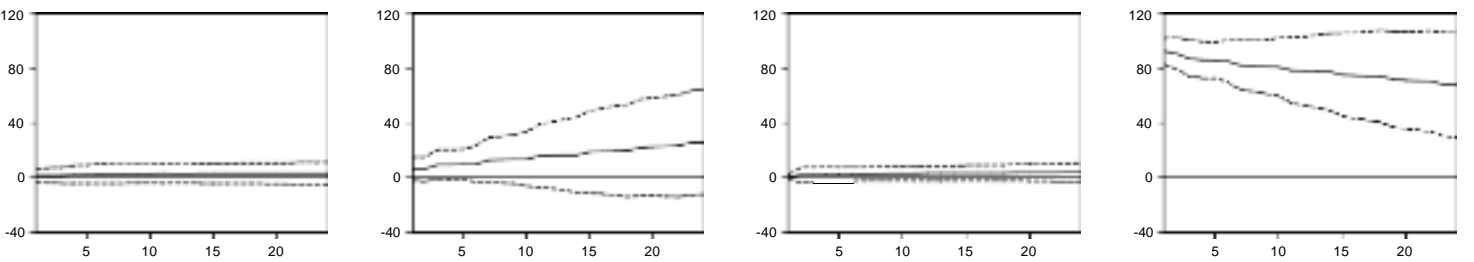

\subsection{Granger Causality}

We used the Granger causality test to investigate the nature of the causality of stock returns (RET), level of economic activity (Y), inflation (PI) and interest rates (R) for Argentina, Brazil, Chile and Mexico.

The results obtained are summarized in Table 6 . It should be remembered that the null hypothesis is that a given variable $\mathrm{X}$ does not cause another variable $\mathrm{Z}$ in the Granger sense. If this hypothesis is rejected, there are indications that the past values of $X$ influence $Z$ today. Or, stated another way, knowing the past values of $X$ helps predict the value of $Z$ today.

The notation used is as follows: causality of $\mathrm{X}$ to $\mathrm{Z}$ is denoted by $X \rightarrow Z$.

The table tests the bidirectional causality between the variables in question and reports the value of the test statistic, as well as its p-value and the result of the test in terms of rejection of the null hypothesis or not.

For Brazil there appears to be a bidirectional relation between Y and R. However, for the other variables it is not possible to reject the null hypothesis of no causality in the Granger sense.

For Chile there appears to be a bidirectional relation between economic activity $(\mathrm{Y})$ and inflation (PI). Additionally, Y causes interest rates (R) and R causes stock returns (RET). 
For Mexico, interest rates (R) cause stock returns (RET) and inflation (PI) causes interest rates $(\mathrm{R})$ in the Granger sense.

Finally, in the case of Argentina, interest rates (R) and inflation (PI) have a bidirectional causality relation in the Granger sense.

Table 6: Granger Causality Tests between the Variables

\begin{tabular}{|c|c|c|c|c|}
\hline País & Direção da Causalidade & Estatística Qui-Quadrado & P-valor & Decisão \\
\hline \multirow[t]{12}{*}{ Brasil } & $\mathrm{Y} \rightarrow \mathrm{R}$ & 45,34536 & 0,0000 & rejeito \\
\hline & $\mathrm{Y} \rightarrow \mathrm{PI}$ & 14,5873 & 0,2022 & não rejeito \\
\hline & $\mathrm{Y} \rightarrow \mathrm{RET}$ & 16,95204 & 0,1093 & não rejeito \\
\hline & $R \rightarrow Y$ & 22,13993 & 0,0233 & rejeito \\
\hline & $\mathrm{R} \rightarrow \mathrm{PI}$ & 6,330984 & 0,8504 & não rejeito \\
\hline & $\mathrm{R} \rightarrow \mathrm{RET}$ & 10,78447 & 0,4615 & não rejeito \\
\hline & $\mathrm{PI} \rightarrow \mathrm{Y}$ & 6,381329 & 0,8467 & não rejeito \\
\hline & $\mathrm{Pl} \rightarrow \mathrm{R}$ & 12,33488 & 0,3390 & não rejeito \\
\hline & $\mathrm{Pl} \rightarrow \mathrm{RET}$ & 19,07295 & 0,0598 & não rejeito \\
\hline & $\mathrm{RET} \rightarrow \mathrm{Y}$ & 8,782413 & 0,6420 & não rejeito \\
\hline & $\mathrm{RET} \rightarrow \mathrm{R}$ & 8,453498 & 0,6722 & não rejeito \\
\hline & $\mathrm{RET} \rightarrow \mathrm{PI}$ & 11,55602 & 0,3979 & não rejeito \\
\hline \multirow[t]{12}{*}{ Chile } & $\mathrm{Y} \rightarrow \mathrm{R}$ & 25,44309 & 0,0078 & rejeito \\
\hline & $\mathrm{Y} \rightarrow \mathrm{PI}$ & 32,06181 & 0,0007 & rejeito \\
\hline & $\mathrm{Y} \rightarrow \mathrm{RET}$ & 5,307715 & 0,9154 & não rejeito \\
\hline & $R \rightarrow Y$ & 11,10146 & 0,4348 & não rejeito \\
\hline & $\mathrm{R} \rightarrow \mathrm{PI}$ & 15,10749 & 0,1776 & não rejeito \\
\hline & $\mathrm{R} \rightarrow \mathrm{RET}$ & 22,83573 & 0,0186 & rejeito \\
\hline & $\mathrm{PI} \rightarrow \mathrm{Y}$ & 25,99687 & 0,0065 & rejeito \\
\hline & $\mathrm{Pl} \rightarrow \mathrm{R}$ & 8,661116 & 0,6531 & não rejeito \\
\hline & $\mathrm{PI} \rightarrow \mathrm{RET}$ & 20,21232 & 0,0425 & não rejeito \\
\hline & $\mathrm{RET} \rightarrow \mathrm{Y}$ & 5,748165 & 0,8896 & não rejeito \\
\hline & $\mathrm{RET} \rightarrow \mathrm{R}$ & 6,482995 & 0,8393 & não rejeito \\
\hline & $\mathrm{RET} \rightarrow \mathrm{PI}$ & 3,994257 & 0,9701 & não rejeito \\
\hline \multirow[t]{12}{*}{ México } & $\mathrm{Y} \rightarrow \mathrm{R}$ & 5,161281 & 0,7402 & não rejeito \\
\hline & $\mathrm{Y} \rightarrow \mathrm{PI}$ & 10,49642 & 0,2319 & não rejeito \\
\hline & $\mathrm{Y} \rightarrow \mathrm{RET}$ & 12,8162 & 0,1183 & não rejeito \\
\hline & $R \rightarrow Y$ & 15,14644 & 0,0564 & não rejeito \\
\hline & $\mathrm{R} \rightarrow \mathrm{PI}$ & 12,75725 & 0,1205 & não rejeito \\
\hline & $\mathrm{R} \rightarrow \mathrm{RET}$ & 56,21302 & 0,0000 & rejeito \\
\hline & $\mathrm{Pl} \rightarrow \mathrm{Y}$ & 15,28298 & 0,0539 & não rejeito \\
\hline & $\mathrm{Pl} \rightarrow \mathrm{R}$ & 16,77846 & 0,0325 & rejeito \\
\hline & $\mathrm{PI} \rightarrow \mathrm{RET}$ & 10,64651 & 0,2225 & não rejeito \\
\hline & $\mathrm{RET} \rightarrow \mathrm{Y}$ & 8,125298 & 0,4213 & não rejeito \\
\hline & $\mathrm{RET} \rightarrow \mathrm{R}$ & 12,81514 & 0,1184 & não rejeito \\
\hline & $\mathrm{RET} \rightarrow \mathrm{PI}$ & 8,96409 & 0,3453 & não rejeito \\
\hline \multirow[t]{12}{*}{ Argentina } & $\mathrm{Y} \rightarrow \mathrm{R}$ & 4,292674 & 0,5081 & não rejeito \\
\hline & $\mathrm{Y} \rightarrow \mathrm{PI}$ & 4,597411 & 0,4670 & não rejeito \\
\hline & $\mathrm{Y} \rightarrow \mathrm{RET}$ & 2,218208 & 0,8182 & não rejeito \\
\hline & $R \rightarrow Y$ & 5,150677 & 0,3978 & não rejeito \\
\hline & $\mathrm{R} \rightarrow \mathrm{PI}$ & 36,30688 & 0,0000 & rejeito \\
\hline & $\mathrm{R} \rightarrow \mathrm{RET}$ & 10,08691 & 0,0728 & não rejeito \\
\hline & $\mathrm{PI} \rightarrow \mathrm{Y}$ & 15,18407 & 0,0096 & não rejeito \\
\hline & $\mathrm{Pl} \rightarrow \mathrm{R}$ & 12,64556 & 0,0269 & rejeito \\
\hline & $\mathrm{PI} \rightarrow \mathrm{RET}$ & 2,166013 & 0,8257 & não rejeito \\
\hline & $\mathrm{RET} \rightarrow \mathrm{Y}$ & 1,990976 & 0,8504 & não rejeito \\
\hline & $\mathrm{RET} \rightarrow \mathrm{R}$ & 2,811192 & 0,7291 & não rejeito \\
\hline & $\mathrm{RET} \rightarrow \mathrm{PI}$ & 5,171937 & 0,3953 & não rejeit \\
\hline
\end{tabular}

\section{CONCLUSION}

The present study sought to analyze the relations among a set of macroeconomic variables and stock returns for Brazil, Chile, Mexico and Argentina from January 1995 to 
December 2005. The variables used were the stock return, level of economic activity, inflation and interest rate. Based on the impulse response analysis and variance decomposition, it can be affirmed that there is no consistent relationship pattern for these variables for the countries studied. Just as in the study by Canova \& De Nicoló (1997), the patterns found are heterogeneous among the countries.

Another conclusion is that the impulse response and variance decomposition results evidence the low sensitivity of stock returns in relation to the macroeconomic variables. In some cases, mainly in the impulse response analysis, there was a weak relationship between stock returns and interest rates. If interest rate shocks are associated with monetary policy shocks, one of the conclusions of this work is that monetary policy shocks appear to be relevant for Latin American stock markets. However, this evidence is fragile, given the variance decomposition and Granger causality results.

This study focused on the relations among stock returns and macroeconomic variables for important Latin American countries, and found little relevance of economic activity and inflation for returns, while interest rates did seem to be relevant for the stock markets. However, this evidence is not robust. It appears more strongly in the impulse response analysis, but much less so in the variance decomposition and Granger causality tests. 


\section{REFERENCES}

ABDULLAH, D. A. Money growth variability and stock returns: An innovations accounting analysis. International Economic Journal, v.12, n.4, pp. 89-104, 1998.

AJAYI, R. A.; FRIEDMAN, J.; MEHDIAN, S. M. On the relationship between stock returns and exchange rates: Test of Granger causality. Global Finance Journal, v.2, n.9, pp. 241-251, 1998.

BAHMANIOSKOOEE, M.; SOHRABIAN, A. Stock prices and the effective exchange rate of the dollar. Applied Economics, v.24, n.4, pp. 459-464, 1992.

BALDUZZI, P. Stock returns, inflation and the "proxy hypothesis": A new look at the data. Economics Letters, v.48, n.1, pp. 47-53, 1995.

BHATTACHARYA, B.; MUKHERJEE, J. Causal relationship between stock market and exchange rate, foreign exchange reserves and value of trade balance in India: An empirical analysis. Presented at the Fifth Annual Conference on Money and Finance, Indira Gandhi institute of Development Research, Mumbai, India, 2003.

BURGSTALLER, J. Stock markets and the macroeconomy: An empirical assessment using VAR models. Linz, 2002. 161p. Doctoral dissertation presented to the University of Linz, Austria.

CAMPBELL, J. Y.; PERRON, P. Pitfalls and opportunities: What macroeconomics should know about unit roots. In: BLANCHARD, O. J.; FISCHER, S. (Ed.). NBER Macroeconomics Annual 1991. Cambridge: MIT Press, 1991. 69p.

CANOVA, F.; NICOLO, G. Stock Returns, Term Structure, Inflation and Real Activity: An International Perspective, CEPR Discussion Papers 1614, 1997.

CHEN, G.; FIRTH, M.; RUI, O. M. Stock market linkages: Evidence from Latin America. Journal of Banking \& Finance, n. 26, pp. 1113-1141, 2002.

DARRAT, A. F.; MUKHERJEE, T. K. The behavior of the stock market in a developing economy. Economic Letters, v.22, n.23, pp.273-278, 1986.

DICKEY, D. A.; FULLER, W. A. Distribution of the estimators for autoregressive time series with a unit root. Journal of the American Statistical Association, v.74, 366, pp.427-431, 1979.

DICKEY, D. A.; FULLER, W. A. Likelihood ratio statistics for autoregressive time series with a unit root. Econometrica, v.49, n.4, pp.1057-1072, 1981.

ENDERS, W. Applied Econometric Time Series. 1st ed. Iowa: John Wiley \& Sons Inc., 1995, 433p.

FAMA, E. F. Efficient capital markets: A review of theory and empirical work. The Journal of Finance, v.25, n.2, pp.383-417, 1970.

FAMA, E. F. Stock returns, real activity, inflation and money. The American Economic Review, v.71, n.4, pp.545-565, 1981.

FAMA, E. F. Efficient capital markets. The Journal of Finance, v.46, n.5, pp.1575-1617, 1991.

FULLER, W. A. Introduction to Statistical Time Series. New York: John Wiley, 1976. 424p.

GESKE, R.; ROLL, R. The fiscal and monetary linkage between stock returns and inflation. The Journal of Finance, v.38, n.1, p.1-133, 1983.

GJERDE, O.; SAETTEM, F. Causal relations among stock returns and macroeconomic variables in a small, open economy. Journal of International Financial Markets, Institutions and Money, v.9, n.1, pp.61-74, 1999. 
GRANGER, C. W. J. Investigating casual relations by econometric models and cross spectral methods. Econometrica, v.37, n.3, pp. 424-438, 1969.

GRANGER, C. W. J.; HUANG, B. N. and YANG, C. W. A bivariate causality between stock prices and exchange rates: Evidence from recent Asia FLU. Discussion Paper 9809. Department of Economics. University of California at San Diego. 1998.

GUJARATI, D. N. Basic Econometrics, $3^{\text {rd }}$ edition, McGrawHill, London, 1995.

HONDROYIANNIS, G.; PAPAPETROU, E. Macroeconomic influences on the stock market. Journal of Economics and Finance, v.25, n.1, pp. 33-49, 2001.

JARVINEN, J. Essays on industry portfolios and macroeconomic news. Tampere, 2000. 137p. Academic Dissertation (Doctoral) - University of Tampere.

JOHANSEN, S. Estimation and hypothesis testing of cointegration vectors in Gaussian vector autoregressive models. Econometrica, v.59, n.6, pp. 1551-1580, 1991.

JONES, C. M.; KAUL, G. Oil and the stock markets. The Journal of Finance, v.51, n.2, pp. 463-491, 1996.

KNOW, S. C.; SHIN, T. S. Cointegration and causality between macroeconomic variables and stock market return. Global Finance Journal, v.10, n.1, pp. 71-81, 1999.

LEE, B. S. Causal relations among stock returns, interest rate, real activity and inflation. The Journal of Finance, v.47, n.4, pp. 1591-1603, Sept. 1992.

LJUNG, G.; BOX, G.; On a measure of lack of fit in time series models. Biometrika, v.65, n.2, pp. 297-303, 1978.

MAYSAMI, R. C.; KOH, T. S. A vector error correction model of the Singapore stock market. International Review of Economics and Finance, v.9, n.1, pp. 79-96, 2000.

MUKHERJEE, T.; NAKA, A. Dynamic relations between macroeconomic variables and Japanese stock market: An application of a vector error correction model. The Journal of Financial Research, v.18, n.2, pp. 223-237, Summer 1995.

NAJAND, M.; NORONHA, G. Causal relations among stock returns, inflation, real activity and interest rates: Evidence from Japan. Global Finance Journal, v.1, n.9, pp. 71-80, 1998.

NAKA, A.; MUKHERJEE, T.; TUFTE, D. Macroeconomic variables and performance of the Indian stock market. Working Paper, 0698. College of Business Department of Economic \& Finance. University of New Orleans, 1998.

NEIH, C. C.; LEE, C. F. Dynamic relationship between stock prices and exchange rates for G7 countries. The Quarterly Review of Economics and Finance, v.41, n.4, pp. 477-490, 2001.

NUNES, M. S.; COSTA JUNIOR, N. C. A.; SEABRA, F. Cointegração e causalidade entre variáveis macroeconômicas, "risco Brasil" e os retornos no mercado de ações brasileiro. Presented at the Fifth Southern Region Economics Meeting, Florianópolis, 2002.

PERALES, N. A. H.; ROBINS, R. The relationship between Mexican stock market returns and real, monetary and economic variables. Manuscript, ITESM, Graduate School of Business Administration and Leadership, Monterey, Mexico, 2002.

SIMS, C. A. Macroeconomics and reality. Econometrica, v.48, n.1, p.148, 1980. 